\title{
Article \\ Co-Education/Co-Research Partnership: A Critical Approach to Co-Learning between Dudley Street Neighborhood Initiative and Tufts University
}

\author{
Penn Loh ${ }^{1, * \mathbb{D}}$, Zoë Ackerman ${ }^{1}$, Joceline Fidalgo ${ }^{1,2}$ and Rebecca Tumposky ${ }^{1}$ \\ 1 Department of Urban \& Environmental Policy \& Planning, School of Arts and Sciences, Tufts University, \\ 97 Talbot Ave., Medford, MA 02155, USA; zoe.ackerman8@gmail.com (Z.A.); joceline.fidalgo@gmail.com (J.F.) \\ rtumposky@gmail.com (R.T.) \\ 2 Dudley Street Neighborhood Initiative, 550 Dudley St., Roxbury, MA 02119, USA \\ * Correspondence: penn.loh@tufts.edu
}

\section{check for}

updates

Citation: Loh, Penn, Zoë Ackerman, Joceline Fidalgo, and Rebecca Tumposky. 2022. Co-Education/ Co-Research Partnership: A Critical Approach to Co-Learning between Dudley Street Neighborhood Initiative and Tufts University. Social Sciences 11: 71. https://doi.org/ 10.3390/socsci11020071

Academic Editors: Steven McKay and Claudia Lopez

Received: 30 December 2021

Accepted: 4 February 2022

Published: 14 February 2022

Publisher's Note: MDPI stays neutral with regard to jurisdictional claims in published maps and institutional affiliations.

Copyright: (c) 2022 by the authors. Licensee MDPI, Basel, Switzerland. This article is an open access article distributed under the terms and conditions of the Creative Commons Attribution (CC BY) license (https:// creativecommons.org/licenses/by/ $4.0 /)$.

\begin{abstract}
Community-university partnerships that purport to promote the public good are often fraught with institutional and cultural challenges that can contribute to the injustices they seek to address. This paper describes how one partnership has been navigating these tensions through a critical approach to power. The Co-Education/Co-Research (CORE) partnership has been built over the last decade between Tufts University and Dudley Street Neighborhood Initiative, a community organizing and planning group in Boston. We have been co-producing knowledge and action to further community control over development, and we have found that institutional shifts, such as co-governance and the equitable sharing of funding, are leading to longer term impacts for the community partner and breaking down the boundaries between university and community. However, using a relational view of power, we have also found that some of our everyday practices can subtly maintain and reinforce inequities, such as valuing academic knowledge over that of community residents and practitioners. Addressing these cultural and ideological challenges requires critical and reflexive practice. It is messy relational work that requires a lot of communication and trust and, most of all, time and long-term commitment.
\end{abstract}

Keywords: community-university partnership; co-learning; community-engaged research; communityengaged scholarship

\section{Introduction}

Community-university partnerships ${ }^{1}$ (CUPs) often purport to promote the public good and contribute to solving societal problems. Some are explicit about addressing societal injustices and even aspire to co-produce knowledge and action. Yet, these collaborations are fraught with challenges, tensions, and contradictions. Some are institutional, such as the inequitable sharing of benefits and costs, university-driven timetables, and a lack of faculty incentives to work in solidarity with community organizations. Some are more deeply embedded culturally and ideologically, such as university elitism, devaluation of community knowledge, and lack of a critical approach to challenging power relations and systemic oppressions such as racism. Together, these challenges reinforce the separations between universities and marginalized communities, and make co-production more difficult.

This paper describes and assesses one CUP designed to address both institutional and deeper cultural challenges through a co-learning approach. We, the authors, have been involved in this partnership as faculty, students, and a community practitioner. The CoEducation/Co-Research (CORE) partnership has been built over the last decade between Tufts University Department of Urban \& Environmental Policy \& Planning (UEP) and Dudley Street Neighborhood Initiative (DSNI), a community organizing and planning 
group in Boston. Through CORE, we have been co-producing knowledge and action to further community control over development, and build more sustainable and just local economies.

CORE aspires to cultivate sustained, transformative partnerships that co-produce knowledge and action towards a more just, sustainable, and democratic society. Starting with joint inquiry and planning, community and university stakeholders integrate teaching, research, and practice over a cycle of three to five years and, if sustained, co-evolve in place over decades. CORE's theory of practice draws upon traditions of action research, service-learning, scholarship of engagement, and universities as anchor institutions. It is a political project inspired by Black radical traditions and the struggles of Third World people to democratize universities and advance racial and economic justice in the 1960s and 70s (Jennings 2000; Dong 2009). CORE is aligned with calls for a Critical Community Engaged Scholarship that can address structural, root causes of racism and other injustices (Gordon da Cruz 2017).

DSNI and UEP piloted a 3-year CORE partnership from 2016-2019, with funding from Tufts University to support DSNI's role as a co-producer. CORE supports transformative learning opportunities for graduate students through semester-long field projects, summer fellowships with DSNI, and master's theses. Through CORE, UEP and DSNI have codesigned a community practicum and a popular education train-the-trainers program for students and the community (Teaching Democracy). CORE has also led to a multi-year federal community action research grant to UEP and DSNI.

Beyond these outcomes, CORE is leading to deeper institutional transformations and longer-term co-creation and power-sharing. During the pilot, two DSNI staff enrolled in UEP's mid-career MPP program, while three UEP graduate students were hired as DSNI staff. Tufts UEP has become DSNI's "research arm", enabling DSNI to do more for itself. With CORE support, DSNI launched the Greater Boston Community Land Trust Network (GBCLTN) to support more community land trusts (CLT) in the region and advocate for supportive policies at the city and state levels. The partners are currently engaged in an action research project to strengthen community control over development of an arts and innovation district. Despite these accomplishments, more needs to be done to institutionalize CORE and secure long-term resources within the university, as well as deepen relational practices to shift power relations between the partners.

Our experience so far shows that shifts in institutional resources and frameworks are possible. While these changes may be visible and tangible, attention must also be paid to the actual relations among the people involved. Relational practices are where cultural and ideological power can subtly (or overtly) be exercised to maintain separations and dominance between university and community partners. Everyday micro-practices can reinforce and reproduce a hierarchy of knowledge, which privileges academic knowledge and devalues community and other forms of knowledge (Loh et al. 2021).

This paper begins with more context on the partners and an overview of our method. We then situate our work within the literature on community-university partnerships and lay out our relational view of power. We go on to describe the CORE model and its history and share and discuss the results of a recent program assessment. We conclude with a discussion of what we are learning through our partnership, and how that can contribute to a more critical approach to CUPs.

\section{The Partners}

DSNI is a community-based planning and organizing non-profit dedicated to the revitalization of the Dudley neighborhood of Boston, which includes parts of Roxbury and North Dorchester. Formed in the mid-1980s, DSNI is renowned for establishing community control over development, and for creating a community land trust (CLT) that owns over 30 acres, on which they have developed hundreds of units of permanently affordable housing, as well as parks, urban farms, and a greenhouse (see Medoff and Sklar 1994). DSNI has hundreds of resident members who elect a board of majority residents. Since 
its founding, DSNI has collaborated with many academics, particularly those in urban planning and social work.

Tufts UEP was formed in 1973 as an interdisciplinary professional master's program in public policy to address integrated problems of urban development, land-use planning, design, and social and environmental concerns. Dedicated to "educating practical visionaries", UEP has, since its inception, integrated community partnerships into its curriculum, research, and practice.

UEP and DSNI's relationship spans more than three decades, during which students have conducted numerous Field Projects, internships and master's theses. Prior to CORE, one UEP alumni had been hired as DSNI staff, and three DSNI staff enrolled in UEP's mid-career Master of Public Policy program. Several faculty members have had strong ties to DSNI, beginning with Melvyn Colón, who helped found DSNI and served as board president before lecturing at UEP from 1989 to 2001. James Jennings has also worked with DSNI since its inception, and served as the principal investigator for the U.S. Department of Education Promise Neighborhoods grant led by DSNI, starting in 2012.

Figure 1 shows the key elements of CORE that are highlighted in this paper.

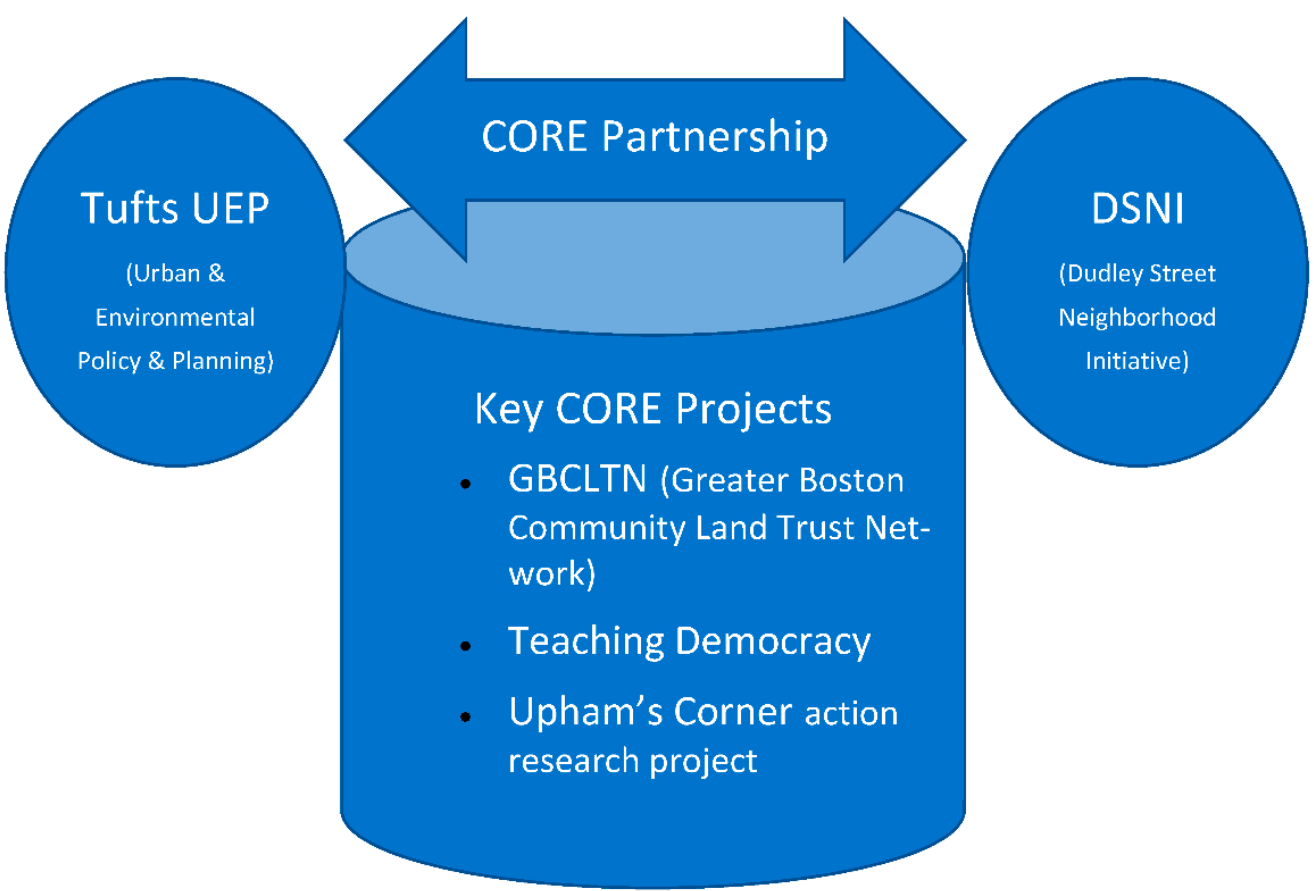

Figure 1. CORE Partnership and Key Projects.

\section{Who We Are and Our Methods}

The authors have each been a part of this long relationship between DSNI and UEP in various and multiple roles. Penn Loh joined the UEP faculty in 2009, after more than 15 years in the environmental justice field, including nine years leading a grassroots organization in Boston that worked intensively with the DSNI. As a UEP lecturer, he has been deepening UEP's community strategies and building CORE. Zoë Ackerman was consistently connected to CORE activities during her time in the master's program at UEP from 2017 to 2020. She worked as a teaching assistant for and wrote her thesis about Teaching Democracy (a popular education training program associated with CORE), interned with another CORE community partner, and was a primary researcher for the program assessment of CORE presented in this paper. Joceline Fidalgo grew up in the Dudley neighborhood, joining DSNI board as a youth, and, after college, served in multiple staff roles over eight years, including Deputy Director. She started UEP's mid-career Master of Public Policy (MPP) in 2017 and, after leaving DSNI staff in 2020, was a research assistant on the action research project funded by the federal grant that she had helped secure. 
Rebecca Tumposky was in the UEP master's program from 2013 to 2016, during which she served as the first graduate assistant to CORE and helped design the first Teaching Democracy pilot. She completed her master's thesis on CORE's co-learning model.

This article is the result of mixed methods, beginning with action research, where the researchers are embedded in the field of study. As CUP practitioners, we inquire about and reflect deeply on our own work in order to develop learnings and insights that can strengthen it. Our various positionalities, as faculty, students, and community practitioners, give us a collective view of our partnership from various university and community perspectives. We also draw upon our archive of notes, concept papers, publicity materials, work outputs, and participant evaluations dating from 2011.

We conducted a program assessment of CORE in spring-summer 2020 to evaluate outcomes and impacts of CORE on the community partner. The assessment included an analysis of CORE documents and outputs as well as seven semi-structured open-ended interviews with DSNI staff involved in CORE. All but one of the interviewees had also been UEP students, including three who became involved in CORE while students and then went on to work at DSNI. This assessment investigated institutional transformations and raised additional questions around power dynamics, which we explore further here.

Several rounds of literature review for various CORE projects and masters' theses inform our approach and the literature review for this paper. Three of us participated in an author collective and joint reflection process in 2020-2021 on the role of power in CUPs, which also informs this paper (see Loh et al. 2021).

\section{Literature Review}

This section first traces the influences on our theory and practice of co-learning and co-production in CORE. We then review key challenges to CUPs. This section concludes with a review of critical and relational approaches to power as applied to CUPs.

\subsection{CORE's Inspirations}

Our co-learning approach to CORE has been inspired by various people and movements, including Dewey and Du Bois from the early 20th century, radical university movements of the 1960s and 70s, and finally the calls for civic renewal of universities from the 1990s. We discuss these influences here to acknowledge their importance to our CUP practice, as well as show the range of traditions and politics that inform CORE.

Widely recognized as one of the founders of experiential education (Boyte 2003; Checkoway 2001; Harkavy and Benson 1998), John Dewey (1916) argued that education was not simply a vessel through which to deliver knowledge or skills, but a vehicle for the development of social consciousness and democratic practice. Education as a vehicle for collective action was also foundational to the Black radical intellectual and political tradition (Jennings 2000; Marable 1986). In the early twentieth century, W. E. B. Du Bois (1903) called for the development of a "talented tenth", which was commonly misinterpreted as an elite intelligentsia, but was actually a call for advanced educational opportunities for African Americans to develop civil rights movement leadership during a period in which the vast majority had no access to education or literacy (Jennings 2000).

We are also inspired by the radical movements of the 1960s and 70s that forced open many university walls. Student activism led to the creation of African American and Ethnic Studies, disciplines that were embedded in community-based research methodologies and an ethic of community service and partnership (Jennings 2000; Dong 2009). The Black radicalism of this period fundamentally challenged the division between university and community (Jennings 2000), demanding more grassroots approaches to university-community engagement, and a curriculum both informed by and useful to Black community struggles. Another outcome of these struggles was the formation of community-based programs and partnerships at public universities, such as San Francisco State University's Community Services Institute, and the College of Public and Community Service at University of Massachusetts Boston. 
Since the 1990s, a body of literature has emerged calling for the renewal of university civic missions (Boyer 1996; Checkoway 2001; Harkavy and Benson 1998). This discussion has included calls for collaborative and community-based research, the development of civic capacities in students through service learning and co-curricular activities, and a tenure promotion process that recognizes and rewards rather than disciplines engagement (Checkoway 2001). Boyer's invocation of a "scholarship of engagement" (Boyer 1996) urges universities to expand their conception of scholarship to include community-engaged pedagogy and services. A number of initiatives have emerged within academia to promote engagement, such as Campus Compact, Carnegie's Community Engagement Classification, and the Talloires Network of Engaged Universities.

From these three eras, we see broad calls for higher education to play a critical role in advancing justice and to break down the divides between universities and marginalized communities. These calls have inspired not only our work in CORE, but the UEP department as a whole. CORE's design is also informed more specifically by the anchor institution conception of universities, service learning, and action research.

In the planning field, universities were reconceived as "anchor institutions", which, because of their fixed locations, capacity for job generation, procurement, and social capital, could help revitalize urban centers suffering from deindustrialization and disinvestment (Initiative for a Competitive Inner City 2011; Harkavy and Hodges 2012; Perry et al. 2009). The U.S. Department of Housing and Urban Development's 1994 Community Outreach Partnerships Centers program (COPC) invested over $\$ 45$ million in more than 100 universities to form University Community Partnerships.

Service-learning has become a widespread engagement strategy at U.S. universities, designed to develop civic-minded graduates. Since the 1990s, some service-learning pedagogies have evolved from a traditional charity or service model to one that emphasizes longer-term community partnership, transformative social change, and becoming part of the community (Angotti et al. 2012; Boyte 1991; Hoyt 2005).

Community-based and action research methods are rooted in a range of theories and practices including Dewey's pragmatism (Dewey 1916), Lewin's organizational psychology (Lewin 1946), Freire's critical consciousness (Freire 1970), Kolb's experiential learning cycle (Kolb 1984), Heron's cooperative inquiry (Heron 1996), and Argyris and Schon's organizational learning and reflexive practice (Argyris and Schon 1996). Under this paradigm, research and learning are tools to improve society, involve subjects in determining research questions, methods and interpretation, and must reflect values of democracy, power sharing, and the centrality of marginalized voices (Ansley and Gaventa 1997). While less recognized, action research is also rooted in the Black liberation social science tradition of the 1960s and 1970s, which worked to develop a research practice driven by and in service of Black community development and liberation (Bell 2006).

\subsection{Challenges of CUPS}

While these trends have helped create space, resources, and will within universities to promote civic missions, there remain deeply embedded challenges to this work. The literature assessing CUP activities provides ample evidence of difficulties stemming from institutional policies and practices and deeper cultural and ideological trends.

Institutional challenges include student learning being prioritized over community needs (Blouin and Perry 2009; Cruz and Giles 2000; Hoyt 2005), rigidity of the academic calendar (Ritterbush 2019; Sandy and Holland 2006; Tryon et al. 2008), short-term semesterto-semester engagements, fragmentation across research, teaching, and practice, production of peer-reviewed articles taking precedence over community benefits (Gomez-Mejia and Balkin 1992; Katz 1973), lack of incentives for tenure-stream faculty because tenure and promotion policies privilege traditional scholarship (Morton and Troppe 1996; Stanton 1994), and prioritization of pursuing large research grants (Fisher et al. 2005).

Cultural challenges include a bias towards positivist forms of knowledge and a devaluing of local and practitioner knowledge (Checkoway 2001; Saltmarsh et al. 2009), excellence 
becoming defined synonymously with selectivity (Jennings 1989), and international work being accorded more status than local community development projects (Fisher et al. 2005; Mohrman et al. 2008).

Both institutional and cultural factors have been raised by critics of HUD's COPC partnerships over their lack of longevity, unequal power dynamics (LeGates and Robinson 1998), promotion of traditional roles of expertise (Hoyt 2010), insufficient internal assessment (Rubin 2000), and reinforcement of the elite status of universities (Boyle and Silver 2005). Without examining these deeply rooted challenges, CUPs run the risk of "reifying the dominant cultural power structures that led to inequitable resource distribution and created a 'public issue' in the first place" (Gordon da Cruz 2017, p. 368).

While our review so far has focused on the university side of CUPs, challenges also arise from the community side. There are ample studies of the impacts of CUPs on students and research, but less focus on the impacts on communities. Community partners in CUPs are often nonprofit organizations that are smaller and less-resourced than their university partners. In their efforts to gain funding, community-based nonprofits often steer themselves towards less controversial and depoliticized projects and methods, what has been referred to as the nonprofit industrial complex (Incite! 2007). This dynamic makes nonprofit community organizations susceptible to transactional and potentially exploitive partnerships with larger and well-resourced universities.

\subsection{A Critical Approach to Power}

A crucial aspect that we believe has been understudied and undertheorized is the role of power in CUPs. Here, we agree with Gordon da Cruz (2017) that critical race theory can help advance CUP theory and practice. A critical theory approach implicates universities as part of the dominant structures through history that have and continue to (re)produce white supremacy and other structural inequities. This approach asks whose knowledge and interests are being engaged and centered in CUPs. A critical approach goes beyond broad calls for contributing to the public good or civic renewal. It requires examining power relations, being explicit about addressing injustices (including racism), and working to transform the institutions (including universities) that have contributed to producing those injustices in the first place. It also surfaces the contributions of activist scholars, often of color, who have long been practicing a critically engaged scholarship with marginalized communities (Hale 2008).

An explicit theory of power can complement the critical theory approach. Power in CUPs is often examined only at the institutional level, where power is a resource to be balanced and shared. While the institutional level is critical, we believe it is insufficient to address the deeply embedded ideological and cultural aspects of power that also operate at the interpersonal level. Thus, we draw on a relational view of power as theorized by Foucault and post-structural feminists. Power is infused in and through all social relations, whether at the interpersonal or institutional levels. Hanson and Ogunade (2016) explain that "power is neither a commodity nor solely embodied in a person, institution or structure to be used for organisational or individual purposes" (p. 43). Gaventa and Cornwall (2008) continue: "For Foucault, power works through discourses, institutions and practices that are productive of power effects, framing the boundaries of possibility that govern action" (p. 175). Power is also inextricably bound up with knowledge. "Power and knowledge directly imply one another ... there is no power relation without the correlative constitution of a field of knowledge, nor any knowledge that does not presuppose and constitute at the same time power relations" (Foucault 1977, p. 27).

While Foucault examined everyday micro-practices and how power and knowledge can create regimes of truth that can reinforce subjugation and dominance, he also saw power as a creative force. "Foucault affirms 'the right ... to rediscover what one is and all that one can be' (Foucault 1979, p. 145)" (Foucault as cited in Gaventa and Cornwall 2008). If dominance and inequalities are produced through relations, then they can also be transformed through them. 
There are several implications of a post-structural relational view of power for understanding power relations in CUPs. First, interpersonal relationships are central and primary. We agree with Ritterbush (2019, p. 1297) "that these relationships, forged through shared commitment, collective care and acts of consciousness-building take time to cultivate and keep alive, time that doesn't fit neatly into academic temporalities of semesters or tenure processes.". Cahill et al. (2010) see their participatory action research practice as a "feminist praxis of care and solidarity that is decentered, conflicted, and committed to negotiation" (Cahill et al. 2010, p. 408). This centering of relationships is described by Garlick and Palmer (2008; drawing on Bauman 1995) as a relational ethic of being-for. They posit that the neoliberalized university "fosters and favours connections that are fragmentary, momentary, and occasional. The conditions are characterized by values of competition, efficiency and individualism" (Garlick and Palmer, p. 74). Instead of being-for (where each person in a relationship is seen as fully human and precious), neoliberal conditions lead to being-aside (where the other is recognized as present but not a person) and being-with (where the other is recognized as a person but only in-so-much as necessary for a particular transaction).

Second, there are always multiple possibilities for power relations in any communityuniversity engagement. Hanson and Ogunade (2016) point to discursive frictions arising from power imbalances as "neither inherently emancipatory nor repressive" (Hanson and Ogunade, p. 43). "Discursive frictions refer to the 'tensions that can arise when various national, social, organizational, and individual cultural differences materialize in our everyday discourse and practices, often privileging, but at times shifting traditional, colonial, and postcolonial power relations' (Murphy 2012, p. 2)" (Murphy 2012, as cited in Hanson and Ogunade 2016, p. 42). How these differences are navigated can reinforce existing power dynamics and inequalities and/or disrupt and transform them. Cahill (2007) engages in participatory action research "for producing new subjectivities, that in the words of Freire 'affirms men and women as beings in the process of becoming-as unfinished, uncompleted beings in and with a likewise unfinished reality' (Freire (1970) 1997, p. 65; italics original)" (Cahill 2007, p. 270).

Third, critical reflection and reflexive practice are crucial. Without these, CUPs can reinforce and/or contribute to further inequalities. Ritterbush warns of "participatory bluffing" where participatory action research (PAR) has been depoliticized and become a "a strategy to co-opt knowledge in the name of participation (Torre 2009, p. 111)" (Ritterbush 2019, p. 1301). She reflects on her own involvement in "'lite pedagogies'—watered-down, university-permissible, PAR pedagogies and research practices" (Ritterbush 2019, p. 1297), where "methodologically oriented PAR curricula and service-learning frameworks run the risk of creating unilateral, semester-long relationships with communities in which the timing of interactions and contact is dictated by class schedules rather than by the daily and enduring urgency of injustice" (Ritterbush 2019, p. 1301). Gordon da Cruz (2017) outlines a critical approach that asks how CUPs are collaborating in authentic relationships with marginalized communities to develop knowledge that can dismantle structures of inequality, including those that higher education is embedded in.

\section{Co-Research/Co-Education (CORE) History}

Our Co-Research/Co-Education model is the result of engagements starting in 2011 but builds from more than four decades of experience at UEP "educating practical visionaries". Field-based learning and engagement with local practitioners has been a part of the core curriculum since UEP's inception. Faculty have developed programs to train leaders and practitioners in the emerging environmental movement in the 1970s and the community development field in the 1980s and 1990s.

In 2009, Penn Loh was recruited to UEP to help deepen its community strategies. The initial co-learning concept evolved out of interviews with UEP community partners, faculty, and alumni and an analysis of community partners that hosted internships and field projects. We found that there were about a dozen partners that had been collaborating 
with UEP in multiple ways for two to three decades. Yet, there was little planning for engagements beyond a semester or year.

At the same time, several examples inspired the possibilities of a co-learning model applied over time. The East St. Louis Action Research Partnership (ESLARP), MIT@Lawrence, and the UCLA Community Scholars program have each been oriented towards community change and justice, long-term engagements, and integration across the tripartite mission of universities (teaching, research, service). Since 1987, ESLARP has partnered with community organizations in East St. Louis through an empowerment planning and sustained engagement approach that includes action research, technical assistance, community education and capacity-building (Reardon 1998). During the 1990s, ESLARP closely followed the action research cycle, working with local residents to establish priorities and build power and capacity to plan and implement neighborhood improvement projects (Sorensen and Lawson 2011). Similarly, from 1999-2012 MIT@Lawrence, a service-learning partnership of the MIT Department of Urban Studies and Planning (DUSP) had a sustained engagement with community organizations, residents, and youth in Lawrence, a small, working-class city north of Boston. The partnership facilitated collaborative research, neighborhood planning, and development projects (Hoyt 2010). The UCLA Community Scholars program was established after the 1992 unrest in Los Angeles and is a joint program of the Department of Urban Planning and Center for Labor Research and Education. Each year the program brings together community and labor leaders with graduate students to study a critical community issue. Through this program, community and labor leaders have developed relationships and shared analysis that have led to new initiatives, such as the founding of the Los Angeles Alliance for a New Economy (Pastor et al. 2011).

Loh piloted a co-learning approach modeled on the Community Scholars program from 2011 to 2014. The Practical Visionaries Workshop was guided by a steering committee of community partners and engaged 26 graduate students and 28 community participants from 17 community groups to learn together and develop projects focused on building more just and sustainable neighborhoods over the spring semester. This experience laid the foundation for the CORE model. For example, during these three years, we linked student field projects and summer internships to the workshop to build continuity. Each year's learning and projects contributed to the next, such as the exploration of solidarity economies abroad leading to a project the following year to apply these models locally.

By 2015, we developed plans for CORE that would bring together various engagements into a multi-year partnership. We aspired to cultivate sustained, transformative partnerships that co-produce knowledge and action towards a more just, sustainable, and democratic society (see Loh 2016). Starting with joint inquiry and planning, community and university stakeholders integrate teaching, research, and practice over a cycle of three to five years and, if sustained, co-evolve in place over decades (see Figure 2). This model is explicit about challenging the existing power relations that drive the social, racial, economic, and environmental injustices it seeks to ameliorate. These power relations exist not just between university and community, but also within each. UEP seeks to partner with entities led by and composed of those segments of the community that are marginalized and oppressed, and allies who share this social change orientation. The multi-year plan lays out a cycle of praxis-where partners engage in "reflection and action directed at the structures to be transformed" (Freire 1970). These activities are not seen as ends in themselves, but as a means to contribute to a change in the world. This longer time frame allows for more significant community and structural change, as well as institutional transformations in the university.

The first CORE partnership was piloted with DSNI from 2016 to 2019. Among a handful of UEP's community partners, DSNI was the one most ready and willing to commit to a multi-year partnership. It was also the partner with the longest record of collaboration with UEP of over three decades. 


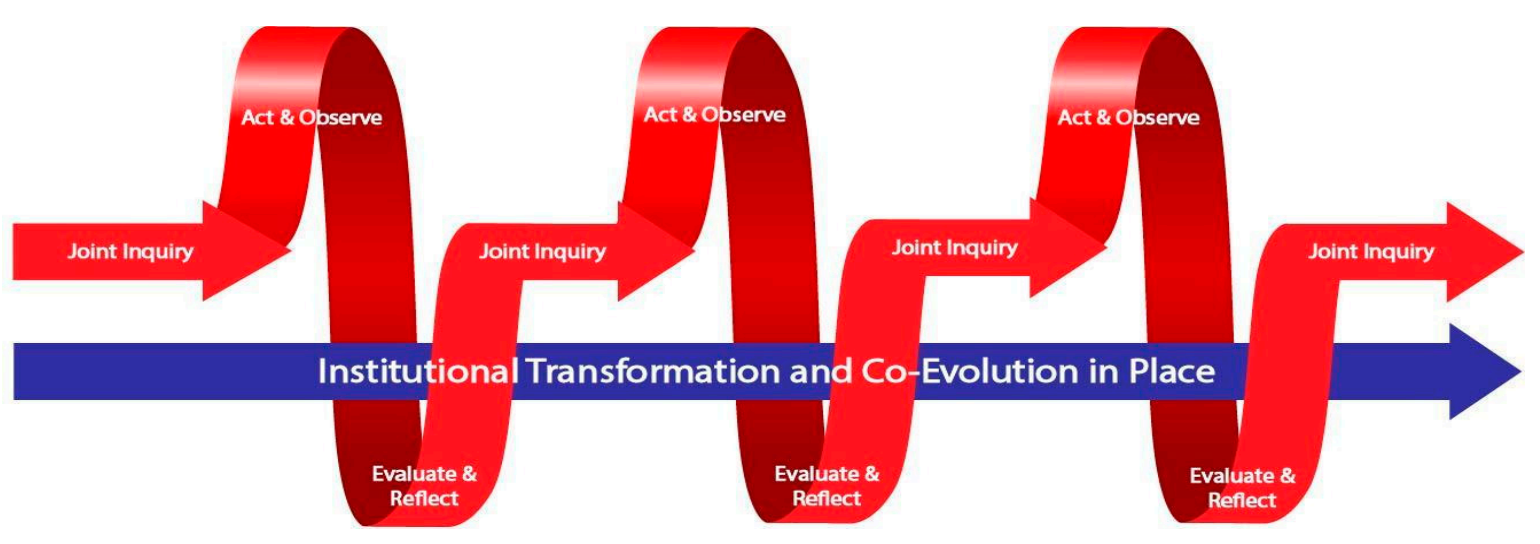

Figure 2. CORE's Co-Learning Model. (Loh 2016).

In 2016, Tufts University and DSNI signed a Memorandum of Understanding (MOU) that identified learning, research, and action goals for a three-year partnership. CORE committed the partners to collaborate on just and sustainable community-controlled economic development, themes that had already been established through the Practical Visionaries Workshops. UEP and DSNI agreed to make decisions together and to jointly raise funds to support DSNI's role in the partnership. This MOU was approved by the Tufts Provost as an official affiliation. Tisch College of Civic Life, at Tufts University, which was already supporting summer fellows and Loh to develop CORE, contributed $\$ 10,000$ annually over the 3-year partnership to support DSNI's role. DSNI estimated that it was spending at least $\$ 10,000$ to $\$ 20,000$ per year on the staff time dedicated to the partnership (the equivalent of $15-25 \%$ of a full-time employee).

The CORE MOU included activities that were already established and resourced, such as a UEP Field Project each spring semester, summer graduate student fellowships, and a co-designed community practicum held every other fall. CORE also led to the development of a popular education train-the-trainers program for students and community, named Teaching Democracy. Through CORE, UEP and DSNI pursued and were awarded a multiyear federal community action research grant in 2018. Table 1 below summarizes the outputs of the three-year pilot.

Table 1. CORE Outputs.

\begin{tabular}{|c|c|c|}
\hline Activity & Description & 2016-2019 Notable Results \\
\hline Field Projects & $\begin{array}{l}\text { Teams of } 4-5 \text { students work } \\
\text { on semester-long projects with } \\
\text { a real-world partner in this } \\
\text { required core course. }\end{array}$ & $\begin{array}{l}\text { Projects completed each spring } \\
\text { with the Greater Boston } \\
\text { Community Land Trust Network } \\
\text { (GBCLTN), facilitated by DSNI. }\end{array}$ \\
\hline Community Practicum & $\begin{array}{l}\text { Course co-designed with } \\
\text { DSNI and other partners and } \\
\text { taught every other year. } \\
\text { About a dozen students join } \\
\text { with practitioners to learn } \\
\text { together and complete } \\
\text { projects for the partners. }\end{array}$ & $\begin{array}{c}2017 \text { theme: Building Community } \\
\text { Controlled Economies in Boston } \\
2019 \text { theme: Solidarity Rising in } \\
\text { Boston and Beyond }\end{array}$ \\
\hline Summer Fellowship & $\begin{array}{l}\text { 10-week full-time graduate } \\
\text { student summer internship } \\
\text { with DSNI, funded by Tisch } \\
\text { College at Tufts. }\end{array}$ & $\begin{array}{l}\text { Two of the three fellows were } \\
\text { students of color. One fellow was } \\
\text { later hired by DSNI as the } \\
\text { part-time coordinator of GBCLTN }\end{array}$ \\
\hline
\end{tabular}


Table 1. Cont.

\begin{tabular}{|c|c|c|}
\hline Activity & Description & 2016-2019 Notable Results \\
\hline Master's Theses & $\begin{array}{l}\text { Required year-long project for } \\
\text { UEP MA degree. }\end{array}$ & $\begin{array}{l}\text { Six students developed master's } \\
\text { theses related to the community } \\
\text { land trust focus of the CORE } \\
\text { partnership with DSNI. One was } \\
\text { later hired into a full-time } \\
\text { position with DSNI's land trust. }\end{array}$ \\
\hline $\begin{array}{c}\text { Guest Lectures and Site } \\
\text { Visits }\end{array}$ & $\begin{array}{l}\text { DSNI staff and leaders host } \\
\text { visits from UEP students and } \\
\text { faculty and come to campus } \\
\text { as guest lecturers } 1-2 \text { times } \\
\text { per year. }\end{array}$ & $\begin{array}{l}\text { DSNI hosted site visits for the } \\
\text { community practicum in } 2017 \text { and } \\
\text { 2019. Visits include students, } \\
\text { other community practitioners, } \\
\text { and also the Dean of Tisch College } \\
\text { in } 2017 .\end{array}$ \\
\hline Research Projects & $\begin{array}{l}\text { Commitment to develop } \\
\text { longer term research projects } \\
\text { related to CORE themes. }\end{array}$ & $\begin{array}{l}\text { In 2018, UEP and DSNI began a } \\
\text { 3-year community action research } \\
\text { project to assess and strengthen } \\
\text { community control in DSNI's } \\
\text { work with City of Boston to } \\
\text { develop a commercial arts and } \\
\text { innovation district. }\end{array}$ \\
\hline $\begin{array}{l}\text { Popular Education and } \\
\text { Leadership Development }\end{array}$ & $\begin{array}{l}\text { Commitment to explore ways } \\
\text { to support DSNI to build } \\
\text { resident capacity and } \\
\text { leadership. }\end{array}$ & $\begin{array}{l}\text { Teaching Democracy, a two-day } \\
\text { popular education } \\
\text { train-the-trainers program for } \\
\text { students and community, was } \\
\text { piloted in 2016, and held again in } \\
2018 \text { and 2019. It is now a regular } \\
\text { credit-bearing course in UEP. }\end{array}$ \\
\hline Community Planning & $\begin{array}{l}\text { Commitment to support } \\
\text { DSNI's planning and } \\
\text { organizing related to CORE } \\
\text { themes. }\end{array}$ & $\begin{array}{l}\text { Through the Practicum and } \\
\text { research projects, UEP has been } \\
\text { supporting the GBCLTN and } \\
\text { DSNI's commercial district } \\
\text { planning efforts. }\end{array}$ \\
\hline Fundraising & $\begin{array}{l}\text { Commitment to raise grants } \\
\text { for joint projects coming out } \\
\text { of CORE. }\end{array}$ & $\begin{array}{l}\text { Received 3-year federal grant } \\
\text { from Corporation for National } \\
\text { and Community ( } \$ 270,000 \text { total). }\end{array}$ \\
\hline
\end{tabular}

\section{Assessing CORE}

In 2020, we conducted a program assessment of CORE, with a focus on better understanding how it has impacted DSNI's programmatic and organizational goals over the term of the 3-year MOU (see Ackerman et al. 2020). Often, the impacts of CUPs on students and universities are better studied than those on community partners. There were four main impacts on DSNI identified in this assessment:

1. Deepening trust and reciprocity between the community and university partners, to the point where UEP has come to be seen as DSNI's "research arm";

2. Co-creation of action and knowledge to further DSNI's mission of community control over development;

3. Cultivation of a deeper bench of leadership at DSNI;

4. Resources and support that valued DSNI's role in the partnership.

Many interviewees felt that the partnership set a new standard for reciprocity and trust in CUPs. The goals and agenda were set jointly and codified in a formal MOU. Harry Smith, a former DSNI senior staff, noted that formalizing the partnership "moved us from a project-by-project orientation to UEP becoming the research arm of DSNI, nimble enough to adapt in the face of change and advance the CLT [community land trust] movement and our work around land use and planning". 
This formal partnership, though, was founded on relational practices that were already in place and continued during the period of the MOU. Bayoán Rosselló-Cornier, a former DSNI organizer who then graduated from UEP's MPP program, saw that UEP and Loh were ready to listen to what the community could offer and to work within the capacities of the partner, not assuming that the community partner was going to go out of its way to set up a meeting to meet the needs of student research. He also appreciated that "DSNI could trust in a certain level of cultural competence of the students they'd work with. Other universities would send teams of white students to take pictures of people's homes. Land trust owners worried that their homes were being sold. You're a white kid in a Patagonia sweater taking pictures ... this is not a safari. You have to approach it carefully, respectfully".

This deep relationship was crucial during the last four years, a time where DSNI's organizational capacity fluctuated dramatically. DSNI had four executive leadership transitions from 2016 to 2020, as well as turnover of key staff. The partnership had to be flexible and adjust plans when these changes occurred. For example, in summer of 2020, DSNI cancelled its youth program, with which UEP had planned to conduct action research. Instead, the UEP team pivoted to support the community planning work in Upham's Corner. Fidalgo, who was Deputy Director at the time of the interview, explained that "despite transitions and staff turnover, UEP still wanted to be connected, to figure out how to shift and adapt its focus. It suggested that the partnership went beyond the university and students being able to benefit, and was about supporting the organization, even through some of its challenges".

CORE also contributed to DSNI's work in critical ways, most notably the launch of the Greater Boston Community Land Trust Network. Two field projects, a co-designed Practicum class, and a master's thesis helped support the startup of this network. At the 2016 public launch event, Loh presented findings from a field project report documenting the benefits of CLTs to more than 100 residents, city officials, and funders. The work of two consecutive summer interns resulted in a CLT operations manual, which is not only used by DSNI but has been shared with CLTs across the country. CORE has also added valuable capacity to DSNI's community planning work with City of Boston to develop an arts and innovation district in the Upham's Corner section of the neighborhood.

CORE has helped cultivate a deeper bench of leaders, through having DSNI staff complete their master's degree at UEP and having UEP graduates work at DSNI. During the partnership, two DSNI staff enrolled in UEP's mid-career MPP program, while three UEP graduate students were hired as DSNI staff. Through learning more about the MPP through CORE, DSNI's Rosselló-Cornier and Fidalgo each decided to attend UEP to hone their skills in policy and planning. UEP gave Rosselló-Cornier "a more high-level and in-depth look, which planted the seeds for the type of work I wanted to do policy-wise". Similarly, Fidalgo wanted the opportunity to step back and critically engage with the neighborhood work, "concerning theory and what other communities are doing both locally and nationally".

CORE also led to the development of a new curriculum and a training resource for both community and university. UEP's community practicum was co-designed with DSNI and created an opportunity for students to work on projects for GBCLTN members. DSNI also worked with UEP and two other community partners to develop Teaching Democracy, a training on popular and participatory education. The course was co-designed and taught by May Louie, a former DSNI senior staffer of 20 years and also a UEP MPP alum. Eliza Parad, an organizer with DSNI at the time, explained that Teaching Democracy offered a way to train their staff and residents in popular education methods without DSNI having to create a curriculum entirely on their own. The training takes place over two 8-h days of interactive exercises and includes roughly equal numbers of UEP students and community members. Piloted in 2016 and then held again in 2018 and 2019, with 20-30 participants per year, it is now a regular course offering of UEP. In the 2016 pilot, DSNI sent six participants, 
including four board members and two staff. In 2018, one DSNI staff and three board members attended.

Importantly, CORE has helped bring additional resources to DSNI as a nonprofit organization. Funding is a perennial challenge for DSNI, one that often limits their ability to participate in CUPs. According to Sharon Cho, a UEP student who then became a part-time staff at DSNI, "oftentimes, with the university, there's an assumption that with a student team or intern, you're offering free research capacity. But it takes time and capacity to support projects and students. So, I think it's valuable to frame it as community partners bringing something to the table, not the other way around. If you're a university, you should be finding a way to pay community organizations". Indeed, this is one of the main ideas of CORE, that the community partner is co-producing knowledge and learning with the university and should be valued and compensated appropriately. The commitment by Tufts (through Tisch College) to provide multi-year funding for DSNI allowed it to plan ahead. CORE also led to the partners securing a three-year federal action research grant from AmeriCorps to support the community planning for an arts and innovation district in Upham's Corner.

\section{Lessons Learned}

The CORE partnership between UEP and DSNI has shown that inequities in CUPs can be addressed through co-governance, deep relationships, sharing of resources, and cross-flow of people. The partnership itself was co-created out of joint inquiry over several years and encoded in a written MOU that set out a formal process of co-governance. The university shared funding to more fully value the community partner as a co-producer. This resource sharing and additional joint fundraising is an important factor, particularly to dampen the effects of the nonprofit industrial complex. The organizational health of DSNI and UEP affects the material survival of their collaboration, as well as their people.

Together we co-produced curricula (e.g., Teaching Democracy) that met learning needs of both UEP and DSNI. The multiple-year time frame also allowed us to support more meaningful contributions to community change, such as the launch of GBCLTN. CORE helped leverage the university's positionality to influence decision makers and funders towards community goals, such as highlighting the value of CLTs at the launch of the GBCLTN. Our continued and thickening relations led to more people flowing across both institutions.

Our assessment, though, also uncovered some tensions and contradictions, arising from deeply embedded dominant cultures and ideologies. For example, with the launch of the GBCLTN, UEP students and faculty provided academic validation and credibility to help advance community goals with decision makers and funders. Loh was the first speaker at the event, providing some framing comments on the importance and potential of CLTs and summarizing a report completed by students. His presentation came before community leaders and CLT residents spoke. By playing this role, he helped give academic credibility to community demands, but also further reinforced knowledge hierarchies. Our university expertise was centered and valued over community experience, even though our research was based on the experience of CLT practitioners, including DSNI.

On the one hand, GBCLTN members wanted to use UEP institutional credibility to influence decision makers and funders on the importance of their work. According to Juan Leyton, DSNI's Executive Director at the time, projects like this "provided a space for the organization to make a case for perspectives about what's important, that cities and foundations may not see as flashy or as valuable". Though it is not easy to prove a causal link between this leveraging of institutional power with changes in policies and resources, this kind of dynamic is often credited with such results. Indeed, the GBCLTN has garnered more funding and has succeeded in shifting some City policies and resources. Yet, Leyton pointed out that "if a community organization has a university validating its ideas, that's both a good and a bad thing. It can feel disempowering to the organization, to need to have information validated by an institution". 
Another example illustrates the limits of institutional agreements, such as the CORE MOU. In the Upham's Corner planning work, Fidalgo was asked, after she had left her DSNI staff role and became a UEP research assistant, to present our action research work to DSNI's board. While this specific request may have seemed uncontroversial, given Fidalgo's strong ties to both DSNI and UEP, she discovered after the meeting that DSNI board members were suspicious about whose interests Tufts was serving and whether they were aligned with DSNI's goals of community control. DSNI's board of 35 members are elected annually, and the majority of seats are reserved for residents, as well as representatives of local non-profits, businesses, and churches. Despite decades of collaboration between people at DSNI and UEP and a formal MOU codifying co-governance and sharing of funding, these perceptions persisted among some board members based on their past experiences with and perceptions of universities. The CORE MOU was negotiated with DSNI staff and signed by the Executive Director, but not deliberated on by the DSNI board.

This situation illustrates the importance of direct relationships in CUPs. While the MOU has lasting effects for Tufts and DSNI as institutions, committing them to resource sharing and collaborative decision making, the partners, through their people, must still enact these agreements through everyday practice. Without more direct interaction with UEP people, DSNI board members defaulted to their common sense to be wary of a university doing research on communities. An MOU can be a tool for co-learning and co-creation, but only to the extent that the MOU and its principles are recognized by all stakeholders (including board members) and made real through everyday practice.

The everyday practices of working together are vital to any process of co-creation. Co-governance is assured not only through an MOU but through the everyday practices of making decisions together. With limited time and resources, it can be easy to miss meetings to check in on progress and/or make unilateral changes to plans, relying on the good faith and trust that has been built. While that can serve for a time, co-governance relations must be constantly renewed.

By sustaining these practices over time, relationships can deepen and endure, moving the collaboration beyond short-term, episodic, semester engagements that are so often critiqued in the CUP literature (Ritterbush 2019; Sandy and Holland 2006; Tryon et al. 2008). The relationships, after all, are what make any institutional commitment real. We are learning that relationships ought to be the goal of CUPs, not the means to another end. This relational ethic requires time to develop and deepen. CORE was only possible in the first place because of previous relationships built over decades. The timing of the GBCLTN launch was designed to coincide with the student Field Project, because the relationship had deepened, and the network organizer understood the semester schedule and what students were capable of. Fidalgo would not have been the one called to represent UEP if she had not had relationships with the board already.

\section{Discussion and Conclusions}

In this paper, we have described our experience in CORE, a multi-year CUP between Tufts UEP and DSNI. CORE was designed to address well-known shortcomings of CUPs, such as being too short-term, undervaluing community expertise and its role in co-production, and focusing on benefits to the university over the community. We found that shared governance and funding, formalized through a 3-year MOU, laid the next stage for deepening our partnership, which had already been decades in the making. CORE helped DSNI to advance not only its programmatic goals, such as building the GBCLTN and furthering community planning in Upham's Corner, but also helped it to build its leadership and capacity. The cross flow of people from DSNI to Tufts and vice versa has helped to make the boundary between university and community more porous. More importantly, it brings people from both institutions into closer and deeper relations.

We have drawn upon a relational view of power to further analyze our partnership and its progress. With a narrower institutional lens on power, we can claim that CORE has helped to redistribute decision making and resources for co-producing knowledge 
and action through our multi-year model that integrates teaching, research, and practice. The relational lens, though, allows us to go deeper, and analyze how we may be affecting more deeply embedded cultural and ideological power relations. For example, we found that while DSNI and its GBCLTN partners wanted to have Tufts academic credibility help validate their work to city officials and funders, they also recognized that as disempowering and reinforcing knowledge hierarchies. We also saw the limits to a formal MOU, where DSNI board members who had not been involved in the formation of the MOU were still wary and distrustful of a university conducting community research.

The relational view of power helps us to center relationships and everyday relations as a unit of analysis. Power is always present in any and all relations. We now return to the three implications of a relational view of power for CUPs that we introduced earlier. First, relationships are central. CORE was designed to center the relationship and not just particular outputs of CUP relations, such as peer-reviewed publications, learning opportunities for students, or funding for a community partner. For DSNI, it made a difference to know that UEP was going to adjust its work and be flexible as DSNI was going through transitions. This relational ethic of being-for is not only something to be pursued as its own goal, but, we would argue, necessary for deeper, long-term partnerships that go beyond transactional outcomes to transformational ones. We agree with Cahill et al. (2010) and Ritterbush (2019) that a relational approach requires a feminist praxis and ethics of care and solidarity that says we are in this together, and accountable to one another.

Second, there are opportunities in everyday relations and discursive frictions for shifting, disrupting, and transforming towards more equitable and emancipatory power relations, but they can also reproduce and reinforce the status quo. In the case of Loh presenting the findings at the GBCLTN launch event, what if instead he worked with GBCLTN members to develop a collaborative presentation, weaving in stories of their experiences in CLTs. In the example of DSNI board members being wary of UEP, what if major partnerships with MOUs were presented to and approved by the board, rather than just the Executive Director and the UEP team attending board meetings periodically to get to know board members better.

These reflections are part of the third implication, which is the importance of reflexive practice. Taking the time and resources to reflect on and learn from our CUP practice is vital. There are many factors that mitigate against doing this well or at all. We were fortunate to have had resources to conduct an assessment of CORE, but even without the resources, time for reflection can be built into the partnership and its co-governance. Practicing critical reflection and care is not easy and requires us to support "students to linger in the fraught spaces of uncertainty and collectivity, which are some of the most important learning spaces for PAR work" (Ritterbush 2019, p. 1305). Transforming power relations does not come through intellectual dialogue only: emotions and embodied practices are critical to releasing/ceding control.

Two main themes arise for us in thinking about the next stage of our work on CORE. One is institutionalizing a culture of relationality. This can be completed through involving more people from both institutions in the partnership, such as DSNI board members and other UEP faculty. There need to be more people in direct relations across the institutions over time, so that the institutional relations are not flowing only through the lead faculty. Regular reflection and learning sessions should be built into the work at UEP and DSNI. Students and staff, who may turnover on a more regular basis, can transmit their knowledge and experience of CORE from one cohort to the next and cultivate a continuing community of practice with CORE alumni. We note that the roles and identities of individuals involved in CORE have become more fluid over time, with individuals moving from participation as students to being staff of DSNI and vice versa.

The other is securing resources to support these relations. More resources can be developed to bring students (particularly BIPOC) affiliated with community partners to UEP. Students can be supported to do year-long fellowships, instead of just summer internships. More programming could be developed, such as Teaching Democracy, to 
engage resident leaders and board members. We would like to challenge ourselves to think about how to develop a seven-to-ten-year partnership.

We hope that in sharing our experience and reflections that we have made a contribution to the theory and practice of CUPs, aligned with critical theory and drawing on a relational view of power. Our experimentation and implementation have led to some successes, challenges, and lessons learned. We will continue our journey towards deeper, more transformational partnerships, ones that ultimately break the binary between community and university itself. This is messy relational work that requires a lot of communication and trust, and most of all, time and long-term commitment.

Author Contributions: P.L. was the lead author responsible for preparing the draft and final editing. R.T. framed the literature review Sections 4.1 and 4.2 and part of the history in Section 5. Z.A. was the lead contributor to Section 6 assessing CORE. Z.A., J.F. and P.L. were responsible for the analysis and discussion in Sections 7 and 8. All authors have read and agreed to the published version of the manuscript.

Funding: This research received no external funding.

Institutional Review Board Statement: The study was conducted in accordance with the Declaration of Helsinki, and approved by the Institutional Review Board (or Ethics Committee) of Tufts University (STUDY00000399, approved for exemption from review on 1 April 2020) for studies involving humans.

Informed Consent Statement: Informed consent was obtained from all subjects involved in the study. Written informed consent has been obtained from the interviewees identified to publish this paper.

Data Availability Statement: The data presented in this study are available in the report An Assessment of the CoResearch/CoEducation (CORE) partnership between Dudley Street Neighborhood Initiative and Tufts University, by Zoë Ackerman, Penn Loh, and Cytharine Alias. 2020. Tufts University. 18 December 2020. Available at: https:/ / pennloh-practical.vision/wp-content/uploads / 2021/02/CORE-Assessement-Final-Report.pdf (accessed on 5 December 2021).

Acknowledgments: We thank all of the community partners who have participated in CORE, especially the staff at Dudley Street Neighborhood Initiative. We also express our gratitude to the university for long-term support to develop, implement, and assess CORE.

Conflicts of Interest: The authors declare no conflict of interest.

\section{Note}

In this paper, we use Community University Partnership to describe the multiple ways that communities and universities collaborate on research, teaching, and practice, including community-engaged research and scholarship.

\section{References}

Ackerman, Zoë, Penn Loh, and Cyatharine Alias. 2020. An Assessment of the CoResearch/CoEducation (CORE) Partnership between Dudley Street Neighborhood Initiative and Tufts University. Medford: Tufts University Department of Urban \& Environmental Policy \& Planning.

Angotti, Tom, Cheryle Doble, and Paula Horrigan, eds. 2012. Service-Learning in Design and Planning: Educating at the Boundaries. New York: New Village Press.

Ansley, Fran, and John Gaventa. 1997. Researching for Democracy \& Democratizing Research. Change: The Magazine of Higher Learning 29: 46-53.

Argyris, Chris, and Donald Schon. 1996. Organizational Learning II. Reading: Addison Wesley.

Bauman, Zygmunt. 1995. Life in Fragments: Essays in Postmodern Morality. Oxford: Blackwell Publishers.

Bell, Ella E. 2006. Infusing race into the US discourse on action research. In Handbook of Action Research-The Concise Paperback Edition. Edited by Peter Reason and Hilary Bradbury. Thousand Oaks: Sage, pp. 48-58.

Blouin, David D., and Evelyn M. Perry. 2009. Whom does service learning really serve? Community-based organizations' perspectives on service learning. Teaching Sociology 37: 120-35. [CrossRef]

Boyer, Ernest L. 1996. The scholarship of engagement. Bulletin of the American Academy of Arts and Sciences 49: 18-33. [CrossRef]

Boyle, Mary Ellen, and Ira Silver. 2005. Poverty, partnerships, and privilege: Elite institutions and community empowerment. City $\mathcal{E}$ Community 4: 233-53.

Boyte, Harry C. 1991. Community Service and Civic Education. Civic Engagement 6. Available online: https://digitalcommons. unomaha.edu/slceciviceng/ 6 (accessed on 5 December 2021). 
Boyte, Harry C. 2003. A different kind of politics: John Dewey and the meaning of citizenship in the 21st century. The Good Society 12: 1-15. [CrossRef]

Cahill, Caitlin. 2007. The Personal is Political: Developing new subjectivities through participatory action research. Gender, Place and Culture 14: 267-92. [CrossRef]

Cahill, Caitlin, David A. Quijada Cerecer, and Matt Bradley. 2010. “Dreaming of ... ": Reflections on Participatory Action Research as a Feminist Praxis of Critical Hope. Affilia: Journal of Women and Social Work 25: 406-16. [CrossRef]

Checkoway, Barry. 2001. Renewing the Civic Mission of the American Research University. The Journal of Higher Education 72: 125-47. [CrossRef]

Cruz, Nadinne I., and Dwight E. Giles. 2000. Where's the community in service-learning research. Michigan Journal of Community Service Learning 7: 28-34.

Dewey, John. 1916. Democracy and Education. New York: MacMillan Company.

Dong, Harvey. 2009. Third World Liberation Comes to San Francisco State and UC Berkeley. San Francisco: Chinese America: History and Perspectives, pp. 95-106.

Du Bois, William Edward Burghardt. 1903. The Negro Problem. New York: James Pott and Company.

Fisher, Robert, Michael Fabricant, and Louise Simmons. 2005. Understanding contemporary university-community connections. Journal of Community Practice 12: 13-34. [CrossRef]

Foucault, Michel. 1977. Discipline and Punish. New York: Vintage Books.

Foucault, Michel. 1979. The History of Sexuality, Part 1. London: Allen Lane.

Freire, Paolo. 1970. Pedagogy of the Oppressed. New York: Continuum.

Garlick, Steve, and Victoria J. Palmer. 2008. Toward an Ideal Relational Ethic: Re-thinking university-community engagement. Gateways 1: 73-89. [CrossRef]

Gaventa, John, and Andrea Cornwall. 2008. Power and Knowledge. In The SAGE Handbook of Action Research, 2nd ed. Edited by Peter Bradbury and Hilary Reason. Los Angeles: Sage Publications, pp. 172-89.

Gomez-Mejia, Luis R., and David B. Balkin. 1992. Determinants of faculty pay: An agency theory perspective. Academy of Management Journal 35: 921-55.

Gordon da Cruz, Cynthia. 2017. Critical Community-Engaged Scholarship: Communities and Universities Striving for Racial Justice. Peabody Journal of Education 92: 363-84. [CrossRef]

Hale, Charles R. 2008. Engaging Contradictions: Theory, Politics, and Methods of Activist Scholarship. Berkeley: University of California Press.

Hanson, Cindy, and Adeyemi Ogunade. 2016. Caught up in Power: Exploring discursive frictions in community research. Gateways 9: 41-57. [CrossRef]

Harkavy, Ira, and Lee Benson. 1998. De-Platonizing and Democratizing Education as the Bases of Service Learning. New Directions for Teaching and Learning 73: 11-20. [CrossRef]

Harkavy, Ira, and Rita A. Hodges. 2012. Democratic Devolution: How America's Colleges and Universities Can Strengthen Their Communities. Washington, DC: Policy Memo, Progressive Policy Institute. Available online: http://www.progressivepolicy.org/2012/10/ democratic-devolution-how-americas-colleges-and-universities-can-strengthen-their-communities (accessed on 5 December 2021).

Heron, John. 1996. Co-Operative Inquiry: Research into the Human Condition. Thousand Oaks, California: Sage.

Hoyt, Lorlene. 2005. A core commitment to service-learning: Bridging planning theory and practice. In From the Studio to the Streets: Service Learning in Planning and Architecture. Edited by Mary C. Hardin, Richard Eribes and Charles Poster. Sterling: Stylus Publishing, pp. 17-31.

Hoyt, Lorlene. 2010. A City-Campus Engagement Theory from, and for, Practice. Michigan Journal of Community Service Learning 17: 75-88.

Incite! 2007. Women of Color Against Violence. In The Revolution Will Not be Funded: Beyond the Non-Profit Industrial Complex. Cambridge: South End Press.

Initiative for a Competitive Inner City. 2011. Anchor institutions and urban economic development: From community benefit to shared value. Inner City Insights 1: 9-11.

Jennings, James. 1989. Race and excellence in American higher education. Trotter Institute Review 3: 7-12.

Jennings, James. 2000. Theorizing black studies: The continuing role of community service in the study of race and class. In Dispatches from the Ebony Tower: Intellectuals Confront the African American Experience. Edited by M. Marable. New York: Columbia University Press, pp. 177-85.

Katz, David A. 1973. Faculty salaries, promotions, and productivity at a large university. The American Economic Review 63: 469-77.

Kolb, David A. 1984. Experiential Learning: Experience as the Source of Learning and Development. Englewood Cliffs: Prentice-Hall.

LeGates, Richard T., and Gib Robinson. 1998. Institutionalizing university-community partnerships. Journal of Planning Education and Research 17: 312-22. [CrossRef]

Lewin, Kurt. 1946. Action research and minority problems. Journal of Social Issues 2: 34-46. [CrossRef]

Loh, Penn, Zoë Ackerman, and Joceline Fidalgo. 2021. A Relational Approach to Transforming Power in a Community-University Partnership. Gateways 14: 1-16. [CrossRef] 
Loh, Penn. 2016. Community-University Collaborations for Environmental Justice: Toward a Transformative Co-Learning Model. New Solutions 26: 412-28. [CrossRef] [PubMed]

Marable, Manning. 1986. W. E. B. Du Bois: Black Radical Democrat. New York: Paradigm Publishers.

Medoff, Peter, and Holly Sklar. 1994. Streets of Hope. Boston: South End Press.

Mohrman, Kathryn, Wanhua Ma, and David Baker. 2008. The research university in transition: The emerging global model. Higher Education Policy 21: 5-27. [CrossRef]

Morton, Keith, and Marie Troppe. 1996. From the margin to the mainstream: Campus Compact's project on Integrating Service with Academic Study. Journal of Business Ethics 15: 21-32. [CrossRef]

Murphy, Alexandra. 2012. Discursive Frictions: Power, identity, and culture in an international working partnership. Journal of International and Intercultural Communication 6: 1-20. [CrossRef]

Pastor, Manuel, Chris Benner, and Martha Matsuoka. 2011. For what it's worth: Regional equity, community organizing, and metropolitan America. Community Development 42: 437-57. [CrossRef]

Perry, David C., Wim Wiewel, and Carrie Menendez. 2009. The university's role in urban development: From enclave to anchor institution. Land Lines 21: 2-7.

Ritterbush, Amy E. 2019. Empathy at Knifepoint: The Dangers of Research and Lite Pedagogies for Social Justice Movements. Antipode 51: 1296-317. [CrossRef]

Reardon, Kenneth M. 1998. Enhancing the capacity of community-based organizations in East St. Louis. Journal of Planning Education and Research 17: 323-33. [CrossRef]

Rubin, Victor. 2000. Evaluating university-community partnerships: An examination of the evolution of questions and approaches. Cityscape 5: 219-30.

Saltmarsh, John, Matthew Hartley, and Patti Clayton. 2009. Democratic Engagement white Paper. Boston: New England Resource Center for Higher Education.

Sandy, Marie, and Barbara A. Holland. 2006. Different worlds and common ground: Community partner perspectives on campuscommunity partnerships. Michigan Journal of Community Service Learning 13: 30-43.

Sorensen, Janni, and Laura Lawson. 2011. Evolution in partnership: Lessons from the East St Louis Action Research Project. Action Research 10: 150-69. [CrossRef]

Stanton, Timothy K. 1994. The experience of faculty participants in an instructional development seminar on service-learning. Michigan Journal of Community Service Learning 1: 7-20.

Torre, Maria Elena. 2009. Participatory action research and critical race theory: Fueling spaces for Nos-otras to research. The Urban Review 41: 106-120. [CrossRef]

Tryon, Elizabeth, Randy A. Stoecker, Amy Martin, Kristy Seblonka, Amy Hilgendorf, and Margaret Nellis. 2008. The challenge of short-term service-learning. Michigan Journal of Community Service Learning 14: 16-26. 